\title{
Drinking water treatment for a rural karst region in Indonesia
}

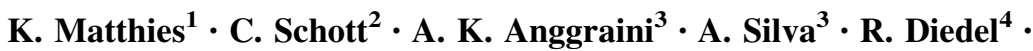 \\ H. Mühlebach ${ }^{2} \cdot$ S. Fuchs ${ }^{3} \cdot$ U. Obst ${ }^{1} \cdot$ G. Brenner-Weiss ${ }^{1}$
}

Received: 19 January 2016/ Accepted: 11 May 2016/Published online: 21 June 2016

(c) The Author(s) 2016. This article is published with open access at Springerlink.com

\begin{abstract}
An interdisciplinary German-Indonesian joint research project on Integrated Water Resources Management (IWRM) focused on the development and exemplary implementation of adapted technologies to improve the water supply situation in a model karst region in southern Java. The project involving 19 sub-projects covers exploration of water resources, water extraction, distribution as well as water quality assurance, and waste water treatment. For the water quality assurance, an appropriate and sustainable drinking water treatment concept was developed and exemplarily implemented. Monitoring results showed that the main quality issue was the contamination with hygienically relevant bacteria. Based on the gained results, a water treatment concept was developed consisting of a central sand filtration prior to the distribution network, a semi-central hygienization where large water volumes are needed to remove bacteria deriving from water distribution and a final point-of-use water treatment. This paper focuses on the development of a central sand filtration plant and
\end{abstract}

G. Brenner-Weiss

gerald.brenner-weiss@kit.edu

K. Matthies

kerstin.matthies@kit.edu

1 Institute of Functional Interfaces, Karlsruhe Institute of Technology, Hermann-von-Helmholtz-Platz 1, 76344 Eggenstein-Leopoldshafen, Germany

2 CIP Chemisches Institut Pforzheim GmbH, Schulberg 17, 75175 Pforzheim, Germany

3 Institute for Water and River Basin Management, Karlsruhe Institute of Technology, Gotthard-Franz-Str. 3, 76131 Karlsruhe, Germany

4 Forschungsinstitut für Anorganische Werkstoffe-Glas/ Keramik-GmbH, Heinrich-Meister-Straße 2, 56203 Höhr-Grenzhausen, Germany some first analysis for the development of a recipe for the local production of ceramic filters for household water treatment. The first results show that arsenic and manganese are leaching from the filters made of local raw material. Though discarding the first, filtrates should be sufficient to reduce arsenic and manganese concentration effectively. Moreover, hydraulic conductivities of filter pots made of $40 \%$ pore-forming agents are presented and discussed.

Keywords Tropic karst aquifer - Water treatment . Appropriate technology $\cdot$ Slow sand filtration - Ceramic filtration · Point-of-use

\section{Introduction}

The aim of the Federal Ministry of Education and Research, Bundesministerium für Bildung und Forschung BMBF-funded German-Indonesian joint research project Integrated Water Resources Management (IWRM) in Indonesia was the development and exemplary implementation of appropriate and sustainable solutions to improve the water supply situation for the population of the rural karst area in the district of Gunung Kidul located within the Province of Yogyakarta Special Region in the southern part of central Java. The population is depending on water from the karst aquifer, as there is almost no surface water available due to the poor retention capacity of the karst setting. Especially in the dry season, people are suffering from water scarcity although there is a huge amount of water present in an underground river system which functions as a natural drainage to the Indian Ocean (Uhlig 1980; Haryono and Day 2004; Tiede et al. 2007).

In the frame of the IWRM project, water quantity was successfully enhanced using an innovative approach in 
terms of an underground hydropower-driven water supply to deliver water from the 100-m deep karst aquifer without use of external energy. Thus, it was possible to secure the water supply for some 80,000 people (Nestmann et al. 2012). However, after the foremost problem was solved and water quantity had been enhanced, further questions had to be addressed, such as water distribution, waste water treatment, and water quality assurance.

Karst aquifers are known to be especially vulnerable to pollutions (Kacaroglu 1999; Goldscheider 2005; Parise and Gunn 2007) due to fast and direct infiltration. In Gunung Kidul, sinkholes allow a direct entering of cow dung and solid waste into the underground river system (Nayono 2014). Furthermore, waste water treatment in the project region is either insufficient or nonexistent. Waste water is partly discharged directly into the ground or collected in unsealed septic tanks (Fach and Fuchs 2010; Nayono et al. 2010). Considering the low retention capacity for pollutants of the karst setting, this leads to a high contamination of the karst aquifer particularly with fecal bacteria. Especially during the rainy season, rainwater is washing pollutants, such as the untreated waste water directly into the karst aquifer.

However, there were no data available about water quality of the karst aquifer or the following water distribution network. Therefore, a thorough water quality monitoring had to be implemented in the project region to evaluate the chemical and microbial contamination of the raw water.

The karst aquifer was contaminated with coliform bacteria throughout the year with relatively low concentrations in the dry season. However, in the rainy season, the count of coliform bacteria and E. coli increased dramatically with extreme peaks at the beginning of the rainy season. In a sampling campaign of monthly samples over two years, values for $E$. coli reached more than 9.600 colony-forming units CFU/100 mL, and total coliforms reached more than $39.000 \mathrm{CFU} / 100 \mathrm{~mL}$ (Matthies et al. 2014). Results of turbidity measurements supported this data showing peaks of more than 500 nephelometric turbidity units NTU at the rainy season (Fuchs et al. 2015). This increase results from heavy rainfall in combination with the poor filtration capacity of the karst bedrock.

Moreover, the contamination within the water distribution network and the physico-chemical properties of the raw water were examined to develop an appropriate drinking water treatment concept.

\section{Source water quality assessment}

\section{Water quality analysis}

The implemented water quality monitoring consisted of a water analysis of the karst aquifer from which the water is

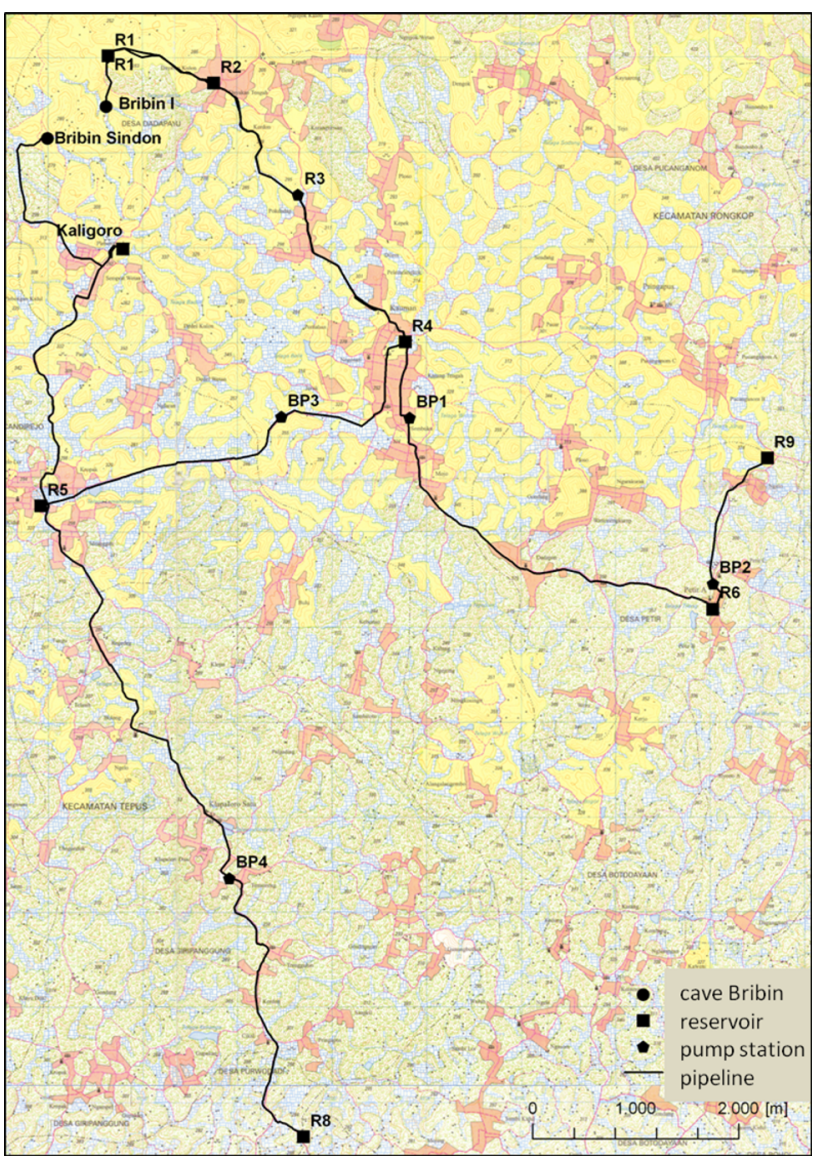

Fig. 1 Distribution network in the project region

extracted (Bribin cave), and the following distribution network comprising 11 reservoirs and pump stations (Fig. 1).

From July 2009 to January 2012, samples were taken once or twice a year from each reservoir along the water distribution network and analyzed using the Colilert ${ }^{\circledR}$ and Enterolert ${ }^{\circledR}$ system (IDEXX Laboratories, USA) following the manufacturer's instructions. Moreover, an aliquot of source water from the Bribin cave (sample taken in July 2006) was transported to Germany and analyzed at the CIP Chemical Institute Pforzheim $\mathrm{GmbH}$ according to the German drinking water regulations (DVGW 2001). pH and temperature were measured directly at the source.

\section{Results and discussion}

Results showed an increasing contamination in the course of the distribution system for the dry season (Matthies et al. 2014). As shown in Fig. 2, bacteria counts were increasing within the distribution system from 17 (E. coli) and 44 (enterococci) in the first reservoir to 100-200 (E. coli) and $960 \mathrm{CFU} / 100 \mathrm{~mL}$ (enterococci) in the last reservoir, though values varied in between. Reasons can be found in 


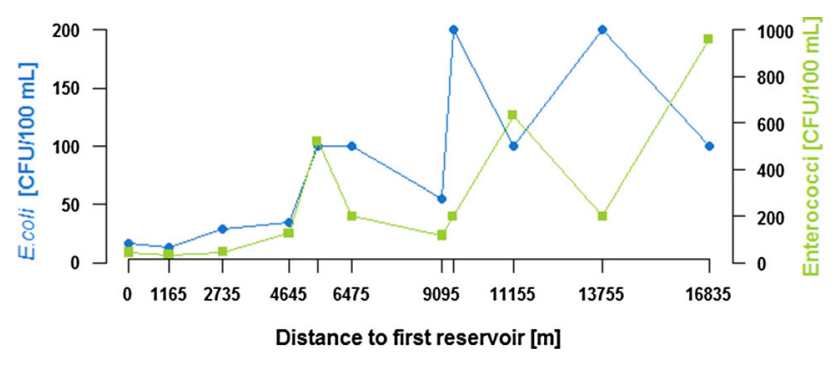

Fig. 2 E. coli and enterococci count (CFU/100 mL) within the distribution network. Data acquired in July 2010 during the dry season. Values for the first reservoir of the distribution network are displayed at $0 \mathrm{~m}$, values for the following reservoirs, and pump stations of the distribution network are given in distance from this first reservoir

the dilapidated pipelines that run mostly above-ground and are heated up by the sun contributing to an intensified growth of bacteria (Matthies et al. 2014). Moreover, leakages and open reservoirs allow an additional contamination of the distributed water.

In the rainy season, the contamination in the distribution system was much higher, though $E$. coli and enterococci counts were decreasing within water distribution from 4.880 (E. coli) and 1.990 (enterococci) in the first reservoir to 840 (E. coli) and $160 \mathrm{CFU} / 100 \mathrm{~mL}$ (enterococci) in the last reservoir (see Fig. 3).

Drinking water regulations in Indonesia as well as WHO guidelines demand $0 \mathrm{CFU} / 100 \mathrm{~mL}$ for total coliforms and E. coli (Menteri Kesehatan Republik Indonesia 2002; WHO 2011). However, the monitoring results never conformed to these guidelines.

In summary, the results showed a significant contamination of the water beginning from the karst aquifer. This contamination is increasing throughout the water distribution system (Matthies et al. 2014). Moreover, the DNA analysis showed that hygienically relevant bacteria, such as Escherichia coli, Enterococcus faecalis, Pseudomonas aeruginosa, Staphylococcus aureus, and Shigella flexneri were present in the distribution system. Consequently, the water needs to be treated before consumption. Otherwise water-borne illnesses are threatening the population.

The water of the karst aquifer was clear and odourless. $\mathrm{pH}$ was 7.46 at a temperature of $27.6{ }^{\circ} \mathrm{C}$. Electrical conductivity was $444 \mu \mathrm{S} / \mathrm{cm}$ and turbidity was $0.36 \mathrm{NTU}$ (spectral absorption coefficient at $436 \mathrm{~nm}: 0.51 / \mathrm{m}$, at $254 \mathrm{~nm}: 7.361 / \mathrm{m}$ ). Fluoride was 0.12 , nitrate 10.3, nitrite 0.02 , ammonium 0.12 , chloride 3.6 , sulphate 6.3 , and boron $0.02 \mathrm{mg} / \mathrm{L}$. Ortho-phosphate was $<0.03 \mathrm{mg} / \mathrm{L}$, adsorbable organic halogen compounds (AOX) were $<0.01 \mathrm{mg} / \mathrm{L}$, and total organic carbon (TOC) was $0.28 \mathrm{mg} / \mathrm{L}$. Sodium had a concentration of 3.1, potassium 1.2, magnesium 7.4, and calcium $91.1 \mathrm{mg} / \mathrm{L}$. The hardness calculated as $\mathrm{CaCO}_{3}$ was $2.58 \mathrm{mmol} / \mathrm{L}$. Acid capacity was $5.04 \mathrm{mmol} / \mathrm{L}$.

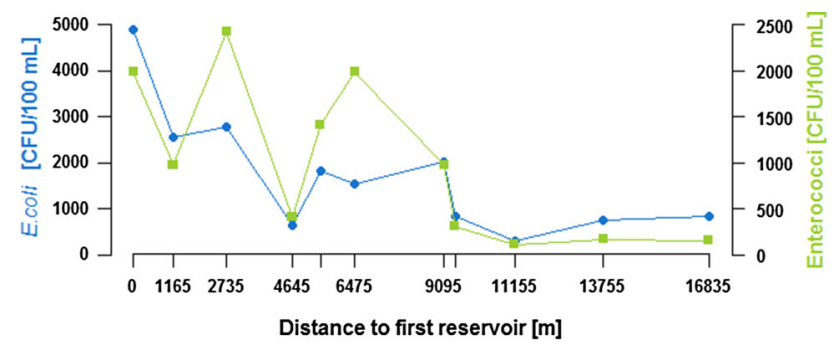

Fig. 3 E. coli and enterococci count (CFU/100 mL) within the distribution network. Data acquired in March 2010 during the rainy season. Values for the first reservoir of the distribution network are displayed at $0 \mathrm{~m}$, values for the following reservoirs, and pump stations of the distribution network are given in distance from this first reservoir

In the water of the karst aquifer, no remarkable concentrations of polycyclic aromatic hydrocarbons, benzenes, cyanides, lightly volatile halogenated hydrocarbons, heavy metals, or pesticides could be detected.

\section{Water treatment concept}

The water quality monitoring showed that water needs to be treated to prevent illnesses. Currently, people boil the water, which is barely sustainable (Matthies et al. 2014). Apart from high consumption of fuel (Sobsey 2002), inhouse boiling on the traditional fires may promote respiratory diseases. Moreover, boiling is often not done properly. Thus, a more sustainable treatment was needed.

Based on the monitoring results and the local boundary conditions, a kind of multibarrier concept was developed that applied simple, low-cost technologies and could mainly do with locally available materials. The water treatment was divided into three phases, including a central sand filtration prior to the distribution network, a semi-central hygienization at village level and a final step at household level (Matthies et al. 2014). This water treatment concept was implemented exemplarily in the form of pilot plants. In Fig. 4, an overview about the whole treatment concept and the corresponding implementation in the project region is given.

\section{Central sand filtration}

As the monitoring results showed extremely high turbidity peaks at the beginning of the rainy season, in a first step, an intermittently operated slow sand filtration should be installed centrally prior to water distribution to remove suspended solids and thus protect the distribution system. Thus, especially the high turbidity peaks in the rainy season can be prevented from entering the distribution system. In cooperation with Indonesian partners, this step of the water treatment concept was implemented exemplarily for 


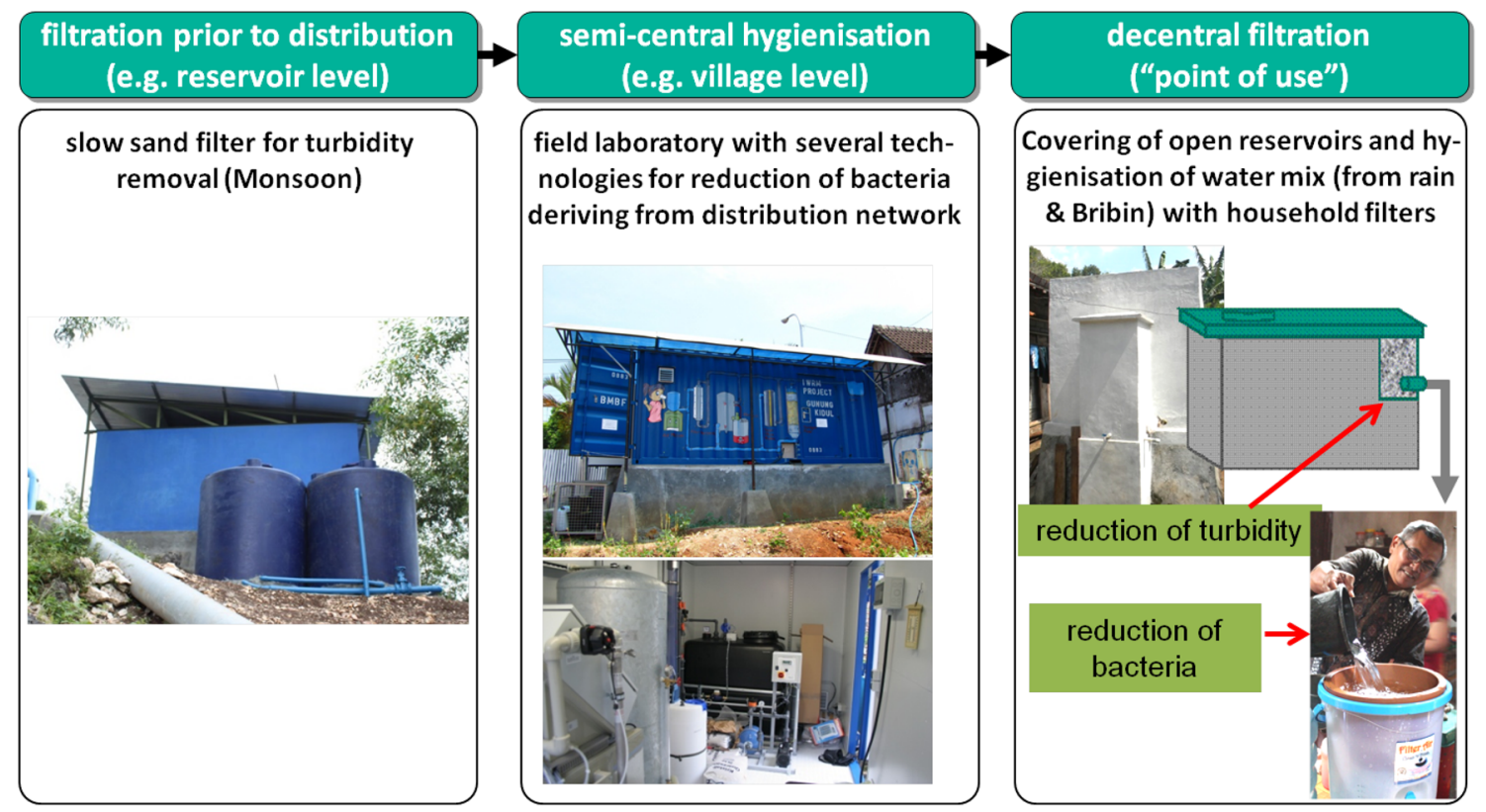

Fig. 4 Three-phase water treatment concept

one part of community directly supplied by the first reservoir, namely reservoir Kaligoro. To develop an optimized design, laboratory experiments with local sands were done. Based on the assumption that $195 \mathrm{~m}^{3} /$ day of water need to be treated to supply the five sub-villages of the supply zone Kaligoro (total input flow in Kaligoro is 6 $192 \mathrm{~m}^{3} /$ day, $3.5 \%$ is used to supply the five sub-villages, $10 \%$ water loss), a total filter bed area of $50 \mathrm{~m}^{2}$ was calculated. The preliminary design included six filter beds with a size of $25 \mathrm{~m}^{2}$ each to allow an alternating operation. However, for the current exemplary implementation, only three such filter beds were installed to validate their performance in field operation (Fuchs et al. 2015). The construction of the sand filter in Gunung Kidul was executed by the Indonesian project partners and finished in early 2015 (Fig. 4).

\section{Experimental work}

To evaluate the suitability of local sands as filter material, different sands were tested, such as lava sand, beach sand, activated $^{5}$ sand, zeolite, and silica sand. From those five types of sand, lava and beach sand showed the best performance on removing turbidity (Fuchs et al. 2015). In addition, a similar study was conducted to investigate the performance of lava and beach sand on handling high turbidity levels. Two filter columns with a six-inch diameter were used during the experiment. Characteristics of these filter columns are shown in Table 1. Both columns were operated intermittently under a constant level of supernatant water.
Table 1 Characteristics of the filter columns

\begin{tabular}{llll}
\hline Filter media & $\begin{array}{l}\text { Effective grain } \\
\text { size d10 }(\mathrm{mm})\end{array}$ & $\begin{array}{l}\text { Uniformity } \\
\text { coefficient } \\
\mathrm{Cu}(-)\end{array}$ & $\begin{array}{l}\text { Permeability of } \\
\text { column }(\mathrm{cm} / \mathrm{s})\end{array}$ \\
\hline Lava sand & 0.25 & 3.06 & $2.416 \times 10^{-2}$ \\
Beach sand & 0.29 & 2.12 & $1.212 \times 10^{-1}$ \\
\hline
\end{tabular}

The influent was artificial raw water with a turbidity value of approximately 500 NTU. To achieve this turbidity level, Indonesian tap water mixed with mud from an underground river in the project region as surrogate material. During the experiment, in which $10 \mathrm{~L}$ were applied to each column every day, the lava sand filter column was operated at a median filtration rate of $0.09 \mathrm{~m} / \mathrm{h}$ and the beach sand filter column was operated at a median filtration rate of $0.24 \mathrm{~m} / \mathrm{h}$. Since the filter columns were built from dark PVC pipe, the growth of a so-called "Schmutzdecke" (comprising filtered particulate matter and biofilm) could not be observed. After start-up of the tests, effluent samples were taken on a daily basis (1-5 samples per day) and evaluated for turbidity. Subsequently, the filter media were tested on performance regarding total coliform and E. coli removal (Fuchs et al. 2015).

\section{Results and discussion}

As far as turbidity removal is concerned, both filter media showed the excellent performance (Fig. 5). Both filtering materials could remove the impurities from 500 to below 


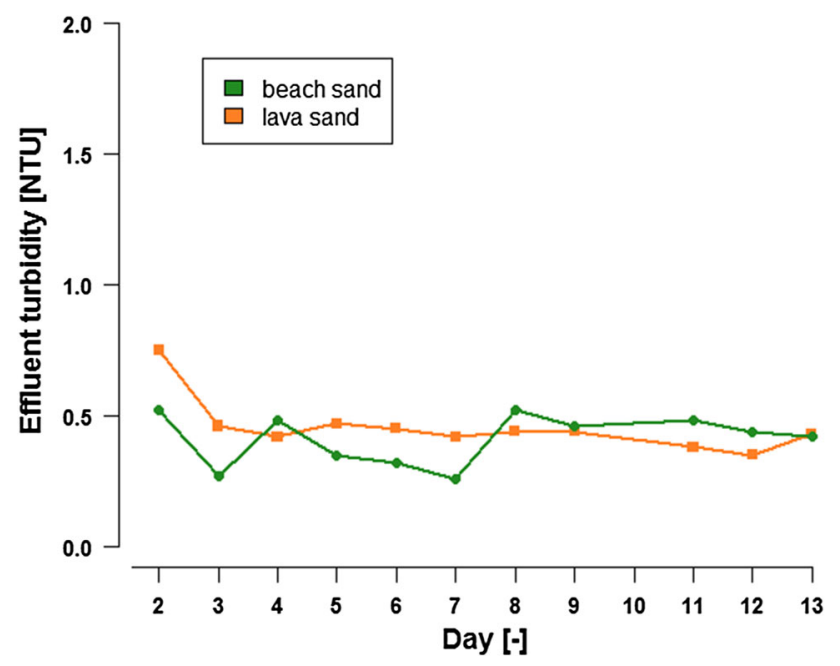

Fig. 5 Effluent turbidity for lava and beach sand filter column

1 NTU which is below the Indonesian standard value for drinking water (Menteri Kesehatan Republik Indonesia 2002). However, due to the characteristics of beach sand which mainly composed of dead shells and coral, an introduction of high contents of carbonate compounds to the water was likely (Fuchs et al. 2015). Therefore, lava sand was chosen as filter material for the slow sand filtration plant (Fig. 6).

As lava sand was chosen, it was tested on total coliform and E. coli removal to get an idea on bacteria removal efficiency. The experimental result was considerably positive, since lava sand achieved an average log removal of 1.26-2.24 $\log _{10}$-units (95.79-99.46\%) for total coliforms and $1.43-1.90 \log _{10}$-units $(96.66-98.37 \%)$ for E. coli (Fuchs et al. 2015). Despite the high removal capacity, the values of total coliform bacteria and $E$. coli remaining in the filtrate were still above the Indonesian standard value for drinking water. Consequently, a disinfection process at the point-of-use was suggested to ensure a safe water quality.

\section{Semi-central hygienization}

The fall-off in water quality during water distribution demands a second phase in terms of a hygienization step after the main distribution network. This hygienization step is implemented at a semi-central level, but close to the consumer to remove bacteria that derive from the dilapidated water distribution system. It is installed once on village level or at public places where a high water amount is needed, for instance at schools.

To find the most appropriate technology for this water treatment step, four selected technologies were installed in an oversea container which functions as a field laboratory (Fig. 7) to test the treatment options under the local conditions (Matthies et al. 2014). As experiments were conducted with untreated water from the karst aquifer, sand filtration was used as a pre-treatment to remove turbidity. Chlorination and UV disinfection were tested as two standard technologies that are widely spread, especially in industrialized countries. Finally, an ultra-filtration system was installed using 50 - or $200-\mathrm{nm}$ ceramic membranes which belong to the less expensive ultra-filtration technologies and are relatively stable and easy to handle. The technologies were chosen based on the local boundary conditions, such as availability of basic material, poor infrastructure and power supply, lack of adequately trained people, and lack of means for costly water treatment systems.

UV disinfection and chlorination were relatively vulnerable to the local conditions, such as fluctuations in power supply or quality of local raw water and chemicals. Results of the experiments under the local conditions suggest that a combination of sand filtration as a pre-
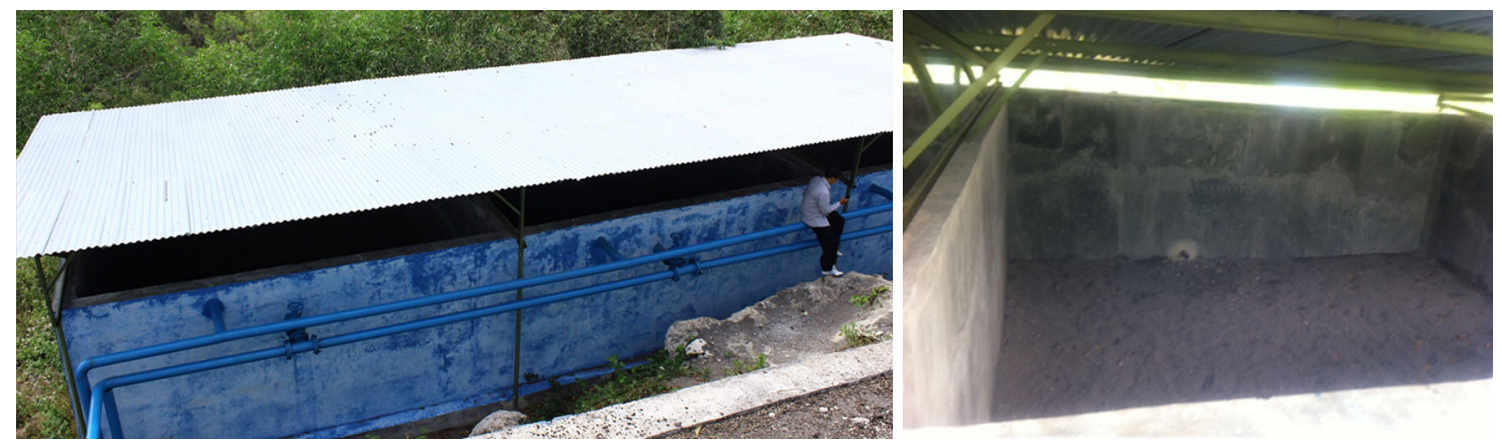

Fig. 6 Left Slow sand filter plant. Right One chamber filled with lava sand as filter material. Currently, on-site validation is being conducted by Indonesian project partners 


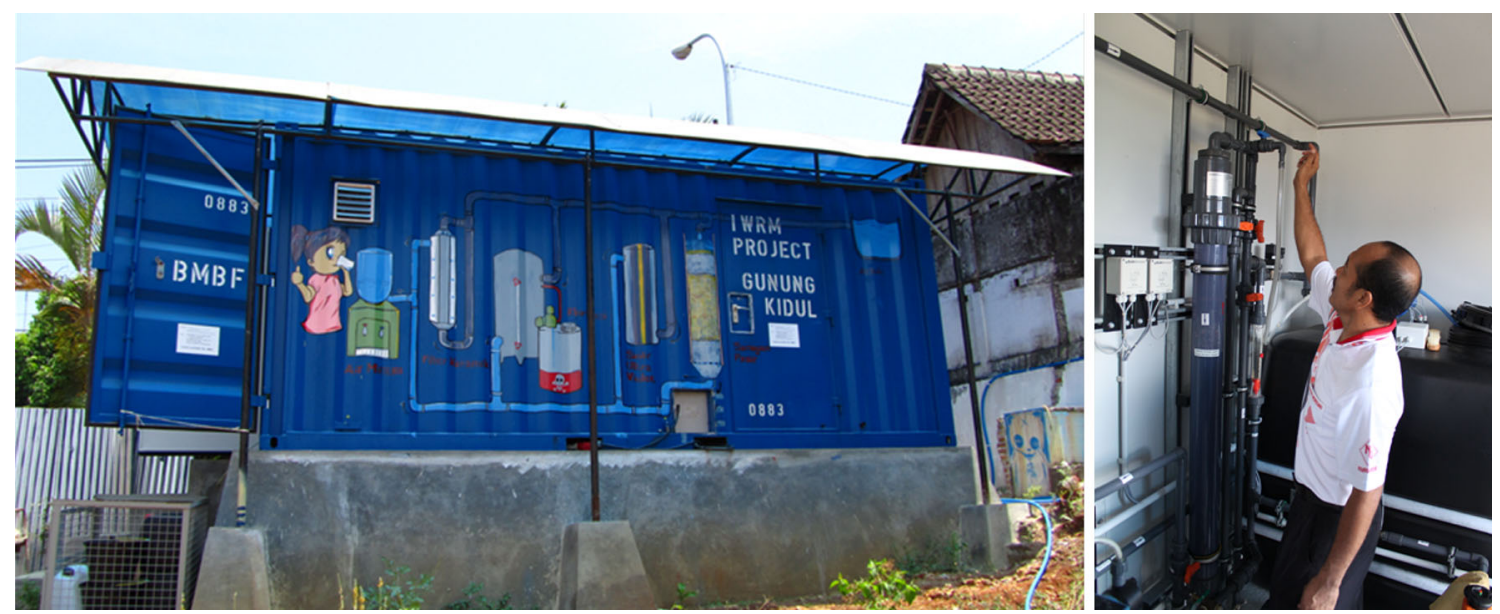

Fig. 7 Field laboratory installed at hospital of Wonosari. Left Picture explains the water treatment technologies in Indonesian language, as the laboratory is situated next to the future public parking for the hospital. Right Inside container

treatment and ultra-filtration with ceramic membranes might be the best solution for the water hygienization step (Matthies et al. 2014).

\section{Point-of-use ceramic filters}

The project region clearly belongs to the regions where piped water is contaminated and water becomes contaminated during storage. Thus, as recommended in the WHO guidelines for drinking water quality, point-of-use water treatment has the potential to significantly improve the health of the users (WHO 2011). The monitoring findings and the growing understanding of the local habits during the work in the pilot village Pucanganom emphasized the need of this third treatment step on household level.

Currently, households in the villages in the project region get tap water irregularly. Normally, three or four households share one tap to save money. To store the water for later use, people fill it into open tanks at the household level which are also used for settling of particles. Mostly, they mix the turbid and hard tap water with rain water to get softer and less turbid water. However, due to the fact that these reservoirs are generally not covered, waste, animals, and other organic material can enter the water and are decomposed in the reservoirs. Therefore, the water is recontaminated and microorganisms are multiplying in the tropical heat. Analysis showed that bacterial counts are relatively high in these tanks, including hygienically relevant bacteria. Moreover, algae as well as cyanobacteria could be detected.

Therefore, a water treatment at the household level was needed. For this treatment step, a point-of-use ceramic filtration was chosen, as it is simple, can be produced locally with locally available clay and is thus more easily accepted by the people. As a pre-treatment, the local open settling reservoirs were optimized through covering and installing a gravel filter at an outlet to remove turbidity.

The use of ceramic filters is promoted by the nongovernmental organization (NGO) Potters for Peace (PFP) and is approved by the WHO (WHO/UNICEF 2012). Filters are already used in several countries, such as Nicaragua (Lantagne 2001a, b), Cambodia (Brown 2007), and Ghana (Halem 2006). As a basis for developing an appropriate filter for the project region, filters produced and promoted in the western part of the Indonesian island Java (Pelita Indonesia, Bandung, and Indonesia) were extensively analyzed in a laboratory as well as in the field. Results showed that filters were efficient in bacteria removal with 3-5 logs (Matthies et al. 2015) and well accepted by the users in the village. An important aim was to facilitate the production of the ceramic filters in local potteries with locally available material.

Thus, a recipe and firing profile needed to be developed for local production of ceramic filters. Therefore, in a first step, filter pots were produced from local clay, mixed with sawdust or rice husks as pore-forming material to assess the suitability of the material.

\section{Experimental work}

As a first step, the pore-forming agents (sawdust and rice husks) were mixed with clay in a volume ratio of 40:60. Pots were fired at a temperature of $850{ }^{\circ} \mathrm{C}$ which was similar to the temperature reported by the manufacturer Pelita Indonesia which was $832{ }^{\circ} \mathrm{C}$ (Matthies et al. 2015). In Fig. 8, the filter pots made of rice husks (left) and sawdust (right) are shown. The filters had a reddish color and a volume of about $1.6 \mathrm{~L}$. It was remarkable that the surface of the filters made of sawdust was much smoother 


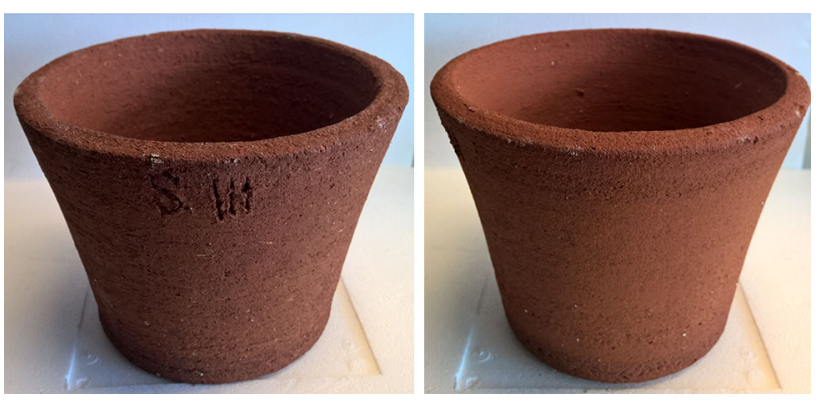

Fig. 8 Ceramic filter pots made of local clay mixed with $40 \%$ rice husks (left) and $40 \%$ sawdust (right)

compared to the filters made of rice husks, which were also quite crumbly.

Pore size distribution An important parameter for flow rate and bacteria retention is the pore size distribution of the ceramic filter material. Therefore, the pore size distribution was determined in duplicates for filters, containing $40 \%$ sawdust or rice husks by the ceramics institute Forschungsinstitut für Anorganische Werkstoffe - Glas/Keramik - GmbH (FGK) in HöhrGrenzhausen, Germany. Ceramic samples were cut into pieces with a diamond saw and dried at $110^{\circ} \mathrm{C}$. About $0.4-1 \mathrm{~g}$ of sample analyzed using mercury intrusion porosimetry following the German standard DIN 66133.

Flow rate and hydraulic conductivity of filter pots To determine the flow rate, pots were fully soaked with tap water and filled completely. The water head was measured every 5-30 min, and flow rate was determined depending on the water head. This measurement was repeated nine times for each filter pot. The hydraulic conductivity was calculated on the basis of the equations described by Schweitzer et al. (2013) deriving from Darcy's equation.

Physico-chemical analysis of filtered water As leaching of heavy metals has been reported of some ceramic filters
(Tun 2009; Halem 2006) and could also be detected in low concentrations in a previous study on the filter produced by Pelita Indonesia (Matthies et al. 2015), a physico-chemical performance analysis was conducted. Therefore, the first filtrates (F1 to F18) of one filter consisting of $40 \%$ sawdust were analyzed at the CIP Chemical Institute Pforzheim $\mathrm{GmbH}$ according to the German drinking water regulations (DVGW 2001). In addition, some filtrates of one filter consisting of $40 \%$ rice husks were included in the analysis.

\section{Results and discussion}

Pore size distribution As shown in Fig. 9, pore sizes ranged from 0.003 to $100 \mu \mathrm{m}$. Incremental intrusion showed one group of peaks between 0.006 and $0.04 \mu \mathrm{m}$ and another group of peaks reaching from 2 to $100 \mu \mathrm{m}$. The ceramic samples containing sawdust showed a group of peaks reaching from 2 to $40 \mu \mathrm{m}$ pore diameter with a maximum incremental intrusion of about $0.036 \mathrm{~mL} / \mathrm{g}$ at $26.8 \mu \mathrm{m}$ pore size. In contrast, samples containing rice husks showed a group of peaks reaching from 2 to $100 \mu \mathrm{m}$ pore size (or even higher) with a maximum incremental intrusion of $0.02 \mathrm{~mL} / \mathrm{g}$ at $36 \mu \mathrm{m}$.

Thus, the ceramic filters made of rice husks as poreforming agents had less big pores compared to those made of sawdust. However, they contained some pores that had a much higher diameter compared to pores in sawdust samples.

Flow rate and hydraulic conductivity of filter pots As expected, the flow rates decreased with decreasing water head for all filters. In Fig. 10, flow rates are shown exemplarily for the nine runs of one filter pot made of rice husks and one made of sawdust.

Throughout the nine runs, a median flow rate of $1.2-1.9 \mathrm{~L} / \mathrm{h}$ for the filter made of rice husks and $1.2-2.4 \mathrm{~L} /$
Fig. 9 Pore size distribution of the ceramic filter pots containing $40 \%$ sawdust or rice husks as pore-forming agents

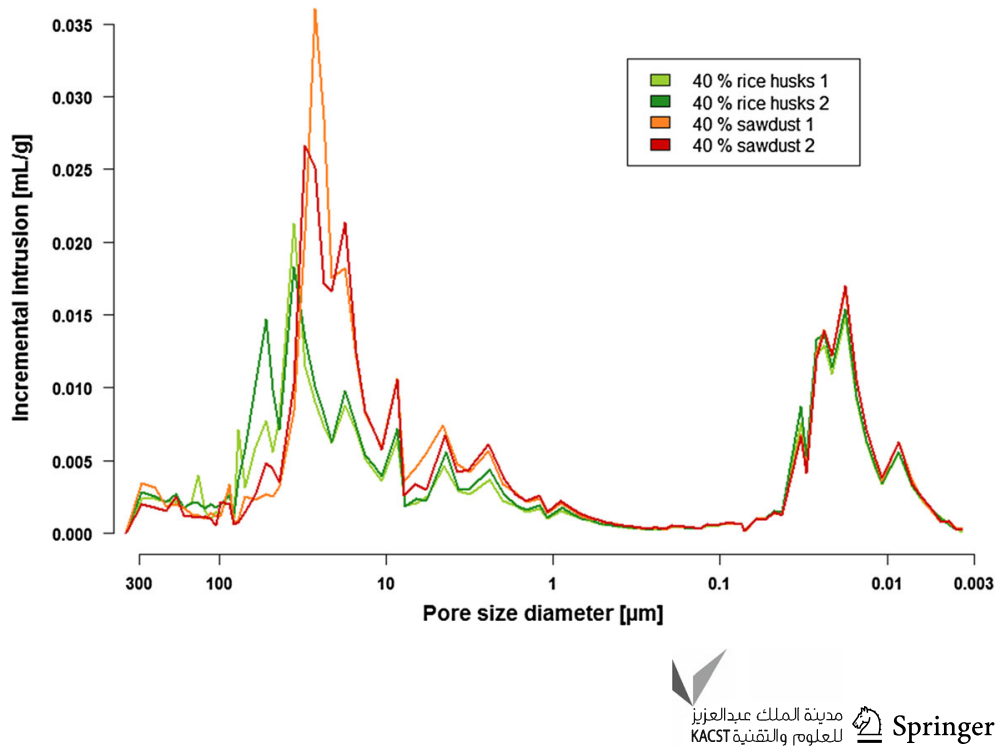




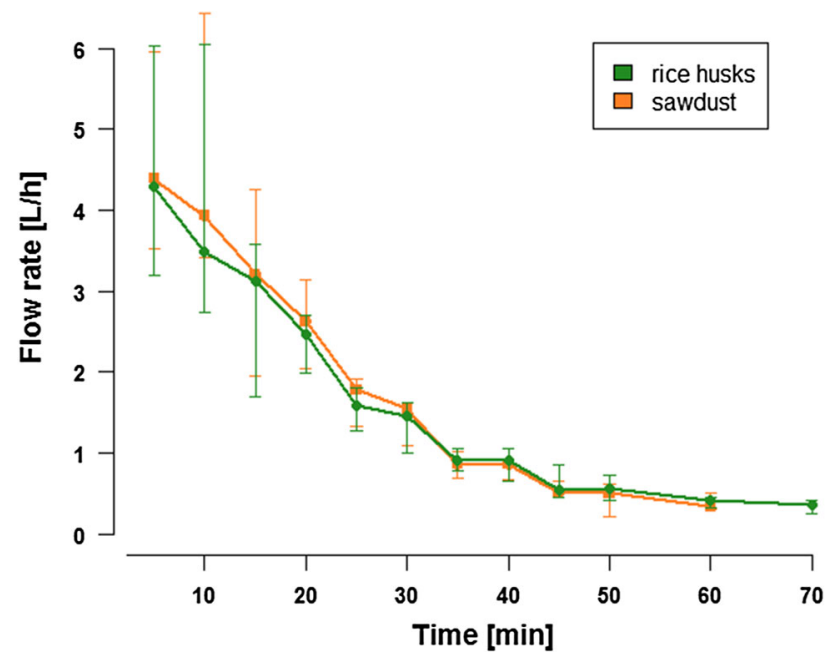

Fig. 10 Flow rate of filter pots containing $40 \%$ sawdust or rice husks as pore-forming agents
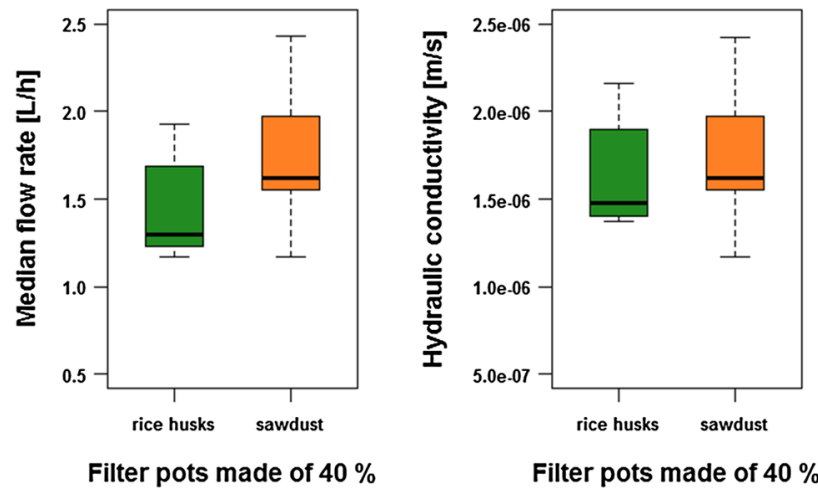

Fig. 11 Median flow rate (left) and hydraulic conductivity (right) of filter pots containing $40 \%$ sawdust or rice husks as pore-forming agents

h for the filter containing $40 \%$ sawdust were obtained (Fig. 11). Thus, hydraulic conductivities were about 1.4 to $2.1 \times 10^{-6} \mathrm{~m} / \mathrm{s}$ for rice husk filters and $1.2-2.4 \times 10^{-6} \mathrm{~m} / \mathrm{s}$ for sawdust filters.

These hydraulic conductivities were higher than those observed in studies on PFP ceramic filters by $\left(1.3-1.37 \times 10^{-7} \mathrm{~m} / \mathrm{s}\right)$, Annan et al. $\left(1.46 \times 10^{-7} \mathrm{~m} / \mathrm{s}\right)$ or Oyanedel-Craver and Smith $\left(1.15-5.01 \times 10^{-7} \mathrm{~m} / \mathrm{s}\right)$ (Halem 2006; Oyanedel-Craver and Smith 2008; Annan et al. 2014). This high flow rate and hydraulic conductivity most probably resulted from the big pore sizes and could be reduced by intensified sieving or milling of the poreforming agents or by the addition of lower concentrations of pore-forming agents to the clay mixture.

Physico-chemical analysis of filtered water Physicochemical analysis of the filtrates obtained from the filter pot containing $40 \%$ sawdust (see Table 2) showed that the $\mathrm{pH}$ of the filtrates seemed slightly increased with values varying from 8.2 to 8.6 for filtrates $\mathrm{F} 2$ to $\mathrm{F} 18$, while the $\mathrm{pH}$ of the feed tap water was about 7.4. Respectively, calcite solubility decreased from -4.7 (F1) to $-67.5 \mathrm{mg} / \mathrm{L}$ (F16), while the tap water showed a value of $-17 \mathrm{mg} / \mathrm{L}$. Apart from an increased conductivity in the first filtrate, no significant changes in electrical conductivity (EC) or hardness could be observed in the filtered water. Values for total organic carbon behaved similarly with a peak of $5.3 \mathrm{mg} / \mathrm{L}$ in the first filtrate and varying values of $0.5-1.1 \mathrm{mg} / \mathrm{L}$ in the following filtrates (tap water $0.6 \mathrm{mg} / \mathrm{L}$ ). Calcium and magnesium concentrations were not significantly influenced by filtration. However, sodium and potassium showed increased concentrations in the first filtrates decreasing again to the level present in the tap water after three (for sodium) to $8 \mathrm{~L}$ (for potassium) were filtered. Values for turbidity and color absorption were increased in the filtrates. The first filtrate had a peak of about 3.2 NTU (tap water $0.15 \mathrm{NTU}$ ) and a color absorption of 62.5 (tap water 0.9 ) at a wave length of $254 \mathrm{~nm}$. In the second filtrate, these values already dropped to $0.8 \mathrm{NTU}$ and to a color absorption at $254 \mathrm{~nm}$ of 23.5. Turbidity values varied from 0.18 to $0.38 \mathrm{NTU}$ in filtrates $\mathrm{F} 12$ to F18, while absorption at $254 \mathrm{~nm}$ continuously decreased further to 5.4 in F18. Regarding leaching of heavy metals, only arsenic and manganese showed increased concentrations in the filtrates. Both elements showed a peak in concentration in the second filtrate. Values for arsenic decreased from $0.036 \mathrm{mg} / \mathrm{L}$ in $\mathrm{F} 2$ to $0.015 \mathrm{mg} / \mathrm{L}$ in $\mathrm{F} 18$. Concentrations for manganese rapidly dropped from $0.18 \mathrm{mg} / \mathrm{L}$ in $\mathrm{F} 2$ to below $0.01 \mathrm{mg} / \mathrm{L}$ in F14.

The second filtrate (F2) of the filter containing $40 \%$ rice husks showed similar values compared to $\mathrm{F} 2$ of the filter made of $40 \%$ sawdust with a concentration of $0.012-\mathrm{mg} / \mathrm{L}$ arsenic and $0.47-\mathrm{mg} / \mathrm{L}$ manganese. Arsenic concentration dropped to $0.006 \mathrm{mg} / \mathrm{L}$ in $\mathrm{F} 7$ and $0.003 \mathrm{mg} / \mathrm{L}$ in F10, while manganese concentration dropped to $0.048 \mathrm{mg} / \mathrm{L}$ in $\mathrm{F} 7$. It is remarkable that less arsenic and more manganese seemed to be leaching from the filters made of rice husks. However, this might be due to varying clay sources. Though manganese concentrations exceeded the maximum permissible value of $0.05 \mathrm{mg} / \mathrm{L}$ following the German drinking water regulation (DVGW 2001) in the first filtrates, the WHO health-based value of $0.4 \mathrm{mg} / \mathrm{L}$ (WHO 2011) was reached only in the second filtrate of the rice husk filter. The threshold value of $0.01 \mathrm{mg} / \mathrm{L}$ for arsenic given by the WHO as well as the German drinking water regulation (DVGW 2001; WHO 2011) was exceeded in the first filtrate of the rice husk filter and the filtrates of the sawdust filter. However, the concentration of manganese was dropping very rapidly and arsenic concentrations were decreasing as well. A flushing of the filter before use is, therefore, strongly recommended. 
Table 2 Selected data for physico-chemical analysis of tap water (TW) and filtrates (F) of the filter pot containing $40 \%$ sawdust

\begin{tabular}{|c|c|c|c|c|c|c|c|c|c|c|c|}
\hline Parameter & TW & F1 & $\mathrm{F} 2$ & $\mathrm{~F} 3+4$ & $\mathrm{~F} 5+6$ & F8 & F10 & F12 & F14 & F16 & F18 \\
\hline $\mathrm{pH}(-)$ & 7.39 & 7.75 & 8.24 & 8.23 & 8.27 & 8.32 & 8.32 & 8.33 & 8.17 & 8.56 & 8.35 \\
\hline $\mathrm{EC}(\mu \mathrm{S} / \mathrm{cm})$ & 716 & 873 & 662 & 629 & 638 & 666 & 688 & 691 & 705 & 729 & 701 \\
\hline Turbidity (NTU) & 0.15 & 3.2 & 0.76 & 0.8 & 0.35 & 0.79 & 0.54 & 0.18 & 0.24 & 0.18 & 0.38 \\
\hline Hardness $\left(\mathrm{mmol} / \mathrm{L} \mathrm{CaCO}_{3}\right)$ & 3.4 & 3.19 & 2.64 & 2.83 & 2.82 & 3.12 & 3.31 & 3.37 & 3.34 & 3.71 & 3.37 \\
\hline As (mg/L) & - & 0.0006 & 0.036 & 0.024 & 0.022 & 0.021 & 0.02 & 0.019 & 0.021 & 0.021 & 0.015 \\
\hline Mn (mg/L) & $<0.005$ & $<0.01$ & 0.18 & 0.15 & 0.14 & 0.091 & 0.031 & 0.016 & $<0.01$ & $<0.01$ & $<0.01$ \\
\hline $\mathrm{Na}(\mathrm{mg} / \mathrm{L})$ & 16.6 & 30.7 & 19.3 & 15.8 & 15.9 & 16.6 & 16.3 & 16.7 & 16.3 & 16.7 & 16.4 \\
\hline $\mathrm{K}(\mathrm{mg} / \mathrm{L})$ & 3.5 & 21.8 & 10.2 & 8.55 & 4.69 & 3.8 & 3.32 & 3.33 & 3.19 & 3.28 & 3.21 \\
\hline $\mathrm{Mg}(\mathrm{mg} / \mathrm{L})$ & 14.7 & 12.1 & 10.6 & 11.4 & 12.2 & 13.2 & 13.6 & 13.9 & 14 & 15.2 & 14.1 \\
\hline $\mathrm{Ca}(\mathrm{mg} / \mathrm{L})$ & 112 & 107.7 & 96.2 & 93.1 & 93 & 103.1 & 110.5 & 111.9 & 112.4 & 123.4 & 111.1 \\
\hline Calcite solubility $(\mathrm{mg} / \mathrm{L})$ & -17 & -4.7 & -24.9 & -29.6 & -31.4 & -42.9 & -49.2 & -51.2 & -47.1 & -67.5 & -53.2 \\
\hline TOC (mg/L) & 0.56 & 5.3 & 0.76 & 0.78 & 1.1 & 0.68 & 0.77 & 0.47 & 0.71 & 0.69 & 0.69 \\
\hline Color (absorption at $436 \mathrm{~nm})(-)$ & $<0.1$ & 0.33 & 0.15 & 0.08 & 0.07 & 0.06 & 0.06 & 0.06 & 0.06 & 0.08 & 0.06 \\
\hline Color (absorption at $254 \mathrm{~nm})(-)$ & 0.9 & 62.5 & 23.5 & 14.4 & 13.9 & 13.1 & 11.6 & 9.6 & 8.8 & 7.2 & 5.4 \\
\hline
\end{tabular}

\section{Summary and conclusion}

An extensive water quality analysis of source water and within a water distribution system in the model region Gunung Kidul of the "IWRM Indonesia" R\&D project revealed the necessity of a kind of multibarrier water treatment concept consisting of a central protecting treatment step prior to the distribution system, a semi-central hygienization where high water volumes need to be treated and a final treatment step at household level.

Preliminary experiments for the development of an appropriate design for a central slow sand filtration showed that both lava and beach sand had a good turbidity removal. However, it was decided to use lava sand as filter material for the slow sand filtration plant which also showed a high removal capacity for total coliform bacteria and E. coli.

Field laboratory experiments revealed that a combination of pre-filtration through a sand filter and ultra-filtration through ceramic membranes might be the best technology for a semi-central hygienization in the project region.

The work with local people in the villages emphasized that a point-of-use water treatment was most important for the treatment concept. For this final water treatment at household level, a ceramic filter was chosen based on the filters promoted by Potters for Peace as these show good bacteria removal and are well accepted by the population. However, these filters were not available in the project region and rarely available in the nearest big city Yogyakarta. Thus, a local production of ceramic filters was planned that would use the already existing infrastructure of potteries in Kasongan, Yogyakarta. This local production of filters should not only provide new jobs, it also should contribute to a more sustainable use of filters, as users would be able to contact the potteries when problems occur. Moreover, a concept for recycling used filters was planned.

To enable a local production of these filters, the locally available raw material was tested for applicability. In this study, filter pots were made of local clay and sawdust as well as rice husks as pore-forming agents.

The use of rice husks as pore-forming agents resulted in bigger pore diameters compared to sawdust, while sawdust had more big pores compared to rice husks. Moreover, the flow rate and hydraulic conductivity of filters made of sawdust were higher compared to rice husk filters. The hydraulic conductivity was quite high compared to literature which suggests that lower concentrations of poreforming agents should be tested as bacteria removal capacity is known to be influenced by pore sizes and flow rate.

Both tested filters showed leaching of arsenic and manganese with initial concentrations above the WHO guideline thresholds. However, the concentrations were decreasing in following filtrates, and a thorough flushing of the filter and discard of first filtrates before use is sufficient to exclude health-relevant concentrations of arsenic and manganese in the filtered water.

Though ceramic filters were well accepted by the local population in a field study (Matthies et al. 2015), to ensure a correct handling of the filter, repeated trainings were needed. One of the facts that were hard to convey was the use of clean filtered water for cleaning of the filter. People did not want to spend this precious clean water for cleaning, and we needed some time to convince them that the 
"clean side" of the filter must not be contaminated by dirty water. One local even bathed the filter in dirty water. These observations supported the idea of an optimized version of the ceramic filter that is easier to maintain.

Thus, in further studies, an optimized recipe and filter design as well as bacteria removal of the filters are addressed. This work is done in collaboration with the Ceramics Institute (FGK) in Höhr-Grenzhausen, Germany.

Acknowledgments The authors would like to thank the coworkers at CIP Chemical Institute Pforzheim GmbH and the Research Institute for Inorganic Materials-Glass/Ceramics-GmbH for the great collaboration and kind assistance. We would also like to thank the German Federal Ministry of Education and Research (BMBF) for financing this project.

Open Access This article is distributed under the terms of the Creative Commons Attribution 4.0 International License (http:// creativecommons.org/licenses/by/4.0/), which permits unrestricted use, distribution, and reproduction in any medium, provided you give appropriate credit to the original author(s) and the source, provide a link to the Creative Commons license, and indicate if changes were made.

\section{References}

Annan E, Mustapha K, Odusanya OS, Malatesta K, Soboyejo WO (2014) Statistics of flow and the scaling of ceramic filters. J Environ Eng 140(11):04014039-1

Brown JM (2007) Effectiveness of ceramic filtration for drinking water treatment in Cambodia. Doctoral Dissertation. Department of Environmental Sciences and Engineering. University of North Carolina, Chapel Hill

DVGW (2001) Verordnung zur novellierung der trinkwasserverordnung (German Drinking Water Regulations). DVGW, Bonn

Fach S, Fuchs S (2010) Design and development of decentralized water and wastewater technologies: a combination of safe wastewater disposal and fertilizer production. Water Sci Technol 62(7):1580-1586

Fuchs S, Silva A, Anggraini AK, Mahdariza F (2015) Planning and installation of a drinking water treatment in Gunungkidul, Java, Indonesia. Water Sci Technol: Water Supply 15(1):42-49

Goldscheider N (2005) Karst groundwater vulnerability mapping: application of a new method in the Swabian Alb, Germany. Hydrogeol J 13:555-564

Haryono E, Day M (2004) Landform differentiation within the Gunung Kidul Kegelkarst, Java, Indonesia. J Cave Karst Stud 66(2):62-69

Kacaroglu F (1999) Review of groundwater pollution and protection in karst areas. Water Air Soil Pollut 113:337-356

Lantagne DS (2001a) Investigation of the potters for peace colloidal silver impregnated ceramic filter report 1: intrinsic effectiveness. Alethia Environmental. Allston, MA. http://web.mit.edu/watsan/ Docs/Other\%20Documents/ceramicpot/PFP-Report1-Daniele\%20 Lantagne, \%2012-01.pdf

Lantagne DS (2001b) Investigation of the potters for peace colloidal silver impregnated ceramic filter, report 2: field investigations.
Alethia Environmental. Allston, MA. http://web.mit.edu/watsan/ Docs/Other\%20Documents/ceramicpot/PFP-Report2-Daniele Lantagne, \%2012-01.pdf

Matthies K, Mendes de Oliveira M, Obst U (2014) Field laboratory for an appropriate water treatment in a tropical karst region. Water Pract Technol 9(4):483-490

Matthies K, Bitter H, Deobald N, Heinle M, Diedel R, Obst U, Brenner-Weiss G (2015) Morphology, composition and performance of a ceramic filter for household water treatment in Indonesia. Water Pract Technol 10(2):361-370

Menteri Kesehatan Republik Indonesia (Ministry of Health of the Republic of Indonesia). (2002) Keputusan Menteri Kesehatan RI NOMOR 907/MenkesENKES/SK/VII/2002 Tanggal 29 Juli 2002 Tentang Syarat-Syarat Dan Pengawasan Kualitas Air Minum. Jakarta, Indonesia. http://perpustakaan.depkes.go.id: 8180/bitstream/123456789/1246/3/KMK907-0702-G.pdf

Nayono S (2014) Development of a sustainability-based sanitation planning tool (SuSTA) for developing Countries. Case Study: integrated water resources management (IWRM) project, Gunung Kidul, Indonesia. Doctoral dissertation, Faculty of civil engineering, The Bauhaus-University Weimar, Germany. https:// e-pub.uni-weimar.de/opus4/frontdoor/index/index/docId/2222

Nayono S, Lehn H, Kopfmüller J, Singer M (2010) Sustainable sanitation as a part of IWRM in the karst area of Gunung Sewu: community acceptance and opinion. Water Pract Technol 4(5): 104

Nestmann F, Oberle P, Ikhwan M, Stoffel D (2012) Experiences Concerning the Implementation of Innovative Technologies and Management Strategies in Emerging Countries-Example IWRM Indonesia. Proceedings IWRM Karlsruhe 2012

Oyanedel-Craver VA, Smith JA (2008) Sustainable colloidal-silverimpregnated ceramic filter for point-of-use water treatment. J Environ Sci Technol 42(3):927-933

Parise M, Gunn J (2007) Natural and anthropogenic hazards in karst areas: recognition, analysis and mitigation. Geol Soc Lon, Spec Publ 279:202

Schweitzer RW, Cunningham JA, Mihelcic JR (2013) Hydraulic modeling of ceramic water filters for point-of-use water treatment. Environ Sci Technol 47(1):429-435

Sobsey MD (2002) Managing water in the home: accelerated health gains from improved water supply. Geneva, World Health Organization (WHO/SDE/WSH/02.07)

Tiede K, Neumann T, Stüben D (2007) Suitability of oxyhydroxides from karst caves as filter material for drinking water treatment in Gunung Sewu, Indonesia. J Soil Sediment. 7(1):53-58

Tun WW (2009) A study of arsenic leaching from colloidal silver ceramic water filters manufactured in Myanmar. UNICEF. http:// www.themimu.info/sites/themimu.info/files/documents/Report_ Arsenic_Leaching_Safe_Water_Systems_2009.pdf

Uhlig H (1980) Man and tropical Karst in Southeast Asia-Geoecological differentiation, land use and rural development. Potentials in Indonesia and other regions. GeoJournal 4(1):31-44

Van Halem D (2006) Ceramic silver impregnated pot filters for household drinking water treatment in developing countries. Master of Science Thesis in Civil Engineering, Delft University of Technology. http://s189535770.onlinehome.us/pottersforpeace/ wp-content/uploads/finalcsfreport_29-10-2-van-dalem1.pdf

WHO (2011) Guidelines for Drinking-water Quality-, 4th edn. WHO, Geneva

WHO, UNICEF (2012) A toolkit for monitoring and evaluating household water treatment and safe storage programmes. WHO, Geneva 